\title{
PERCY IVES, THOMAS EAKINS, AND WHITMAN
}

In discussing the Thomas Eakins photographic series of a nude unidentified old man, Ed Folsom suggests that, if the model is in fact Walt Whitman, then he and Eakins would have had to meet in the early 1880s, not in 1887, the year that Whitman told Horace Traubel he had first met the artist. ${ }^{1}$ Folsom suggests that one possible connection for an earlier meeting could have been Talcott Williams, a prominent Philadelphia journalist who knew both Whitman and Eakins. I would like to suggest another person who might have brought together the poet and the painter/photographer in the early $1880 \mathrm{~s}$.

Percy Ives was the grandson of Elisa Leggett, a Long Island friend of Whitman's who moved to Detroit, Michigan, in the 1860s and corresponded with Whitman in the 1880 s. $^{2}$ Ives arrived in Philadelphia in 1880 to study with Eakins at the Pennsylvania Academy of the Fine Arts, and he quickly paid his respects to Whitman at the poet's Camden, New Jersey, home. Whitman describes Percy at this time as "age 16, a student intends to be an artistlives bachelor's hall fashion in Philadelphia-reads Emerson, Carlyle, \&c-is a son of Lewis T. Ives, Artist-Academy of Fine Arts." 3

Recalling that first trip some sixteen years later, Ives told an interviewer:

We talked of ordinary things. . . . He seemed to be interested in what I had to say, to want to learn something, to know what I thought about things. It seems to me perfectly natural from what I know of Walt Whitman that he should expect to learn something interesting from me as I was then, a mere boy, as from any one else. . . Soon we were getting on finely together. I asked him if I might make a sketch of him and he said yes and so we passed two hours very pleasantly together. When I had finished the sketch he looked at it, but did not make any comment one way or the other. . . . My first impression of Walt Whitman was that of a man who was genial, healthy and wholesome, and while there was nothing sour or morose about him, and though his face was one that could easily break into a smile, I never remember hearing him laugh. . . . It was as if life with him was something too sacred to permit laughter. ${ }^{4}$

On a number of occasions in 1881 and 1882 Whitman made note of visits from young Ives, of whom he seems to have greatly approved. The friendship between the two raises the possibility that Whitman may have met Eakins, through Percy, sometime during Percy's study at the Academy, and thus may prove a step toward eventual verification of current speculation that the Eakins photo of the nude elderly male is of Whitman. Percy Ives may also prove to be the intermediary through whom Eakins came into contact with William Duckett, Whitman's young driver, whom Eakins photographed in the nude sometime between 1886 and 1892. Because Duckett was about the same age as Percy, the two may have met in Camden, with Ives perhaps suggesting that Duckett obtain work as a model for Eakins. ${ }^{5}$

According to the records of the Pennsylvania Academy of the Fine Arts, Percy Ives, son of Elisa Leggett's daughter Margaret and Lewis T. Ives, also a painter, studied with Eakins from 1881 to 1884 (two years before Eakins was forced to leave the Academy). While studying in Philadelphia, young Ives did a small oil portrait of Whitman (1882), now in the Feinberg Collection, Library of Congress, along with preliminary sketches, done by the artist. ${ }^{6}$ Ives 
then went to Paris to continue studying and, while living in Europe, corresponded with Whitman, writing for example in 1887:

I now take the liberty of telling you that there is more of the essence of life and movement in your Leaves of Grass than anything I have ever met with, that it is one of those few books whose vacancy could not be readily supplied by another. A man or woman with any life could not help but be electrified by immense sweeps in those inspiring sentences. Being away from home I think I feel more keenly the spirit of your verses. (Feinberg, 10)

Later Ives moved to Detroit. Like his father, he became a noted portrait painter, though his most important commission, an oil portrait of President Grover Cleveland executed during his time in office, was originally made to Lewis Ives until illness made the undertaking impossible and the son took his place. Percy Ives was a founder of the Detroit Art Institute (originally the Detroit Museum of Art). When he was sixty years old, two years before his death in 1928, he painted another portrait of Whitman.

\section{NOTES}

1 See Ed Folsom, "Walt Whitman's Calamus Photographs," in Betsy Erkkila and Jay Grossman, eds., Breaking Bounds: Whitman and American Cultural Studies (New York: Oxford University Press, 1996), 193-219; and Folsom, "Whitman Naked?," Walt Whitman Quarterly Review 11 (Spring 1994), 200-202. Whitman recalls his first meeting with Eakins in Horace Traubel, With Walt Whitman in Camden, ed. Sculley Bradley (Philadelphia: University of Pennsylvania Press, 1953), 4:155.

2 I investigate the Leggett-Whitman relationship in "Walt Whitman's Long Island Friend: Elisa Seaman Leggett," Long Island Historical fournal 9 (Spring 1997), 223233, from which some of the material in this article is excerpted.

3 Whitman, Daybooks and Notebooks, ed. William White (New York: New York University Press, 1978), 1:210.

4 “Artist-Poet: Reminiscences of Walt Whitman," Detroit Sunday-News Tribune (April 5, 1896); quoted in Charles E. Feinberg, "Percy Ives, Detroit and Walt Whitman," Detroit Historical Society Bulletin 16 (February 1960), 5, 8.

5 For the Duckett photo, see Folsom, "Calamus Photographs," 211.

6 For reproductions of some of the sketches and for more details of Percy Ives's life, see Feinberg, "Percy Ives, Detroit and Walt Whitman," 4-11. 